\title{
Rationales and Applications of Mutuality of Obligations in Iranian Contract Law
}

\author{
Majid Sarbazian $^{1}$ \& Soroush Rostamzad Asli ${ }^{2}$ \\ 1 Assistant Professor at the Law and Political Science Faculty, University of Shiraz, Shiraz, Iran \\ ${ }^{2} \mathrm{PhD}$ candidate in Private Law, Shiraz University, Shiraz, Iran \\ Correspondence: Majid Sarbazian, Assistant Professor at the Law and Political Science Faculty, University of \\ Shiraz, Shiraz, Iran. E-mail: sarbazian20@gmail.com/soroush.lawyer@yahoo.com
}

Received: June 27, 2016

Accepted: July 8, 2016

Online Published: April 15, 2016

doi:10.5539/mas.v10n12p132

URL: http://dx.doi.org/10.5539/mas.v10n12p132

\begin{abstract}
In Iranian laws, commitment is exchangeable if it is of proper and rational interest. In exchangeable contracts, it needs that parties perform their commitments mutually and in the case of not performing the commitments by one party, another one can refuse its commitments as called lien. There are also cases in which some terms are cancelled since they destroy the powers of one party to enforce the other party in performing his commitment. On this basis, the main challenge of present paper is to study the nature and status of mutuality of obligations doctrine in Iranian laws and studying its basics and implications. At the end, it is recognized that although mutuality of obligations is not raised in Iranian laws as a legal doctrine, it is effective in shaping and undertaking an exchangeable commitment.
\end{abstract}

Keywords: mutuality of obligation, consideration, lien, exchangeable contracts

\section{Introduction}

Legal theories are grown in the context of law history, are changed partially or wholly or have survived as before. In this vein, the scope of obligations has observed highest changes, transformations and studies among other fields due to its expansion and importance. There are some differences on shaping the contracts in Iranian and Common Laws. In fact, in Iranian laws, offer and acceptance constructs the contract while in Common Law, a contract is shaped in the case of accumulation of offer, acceptance and a consideration, and in the case of lacking even one of these elements, no contract is established. In Common Law, there are different opinions on consideration mostly on the necessity of rationality of consideration for each party.

Mutuality of obligations doctrine that recognized and used today in Common Law is a theory grown over law history and is raised in contract laws despite of criticisms against it. This rule which shaped by UK laws and has complete link with consideration in UK contract laws has been always exposed by paramount criticisms by legal doctrine. In fact, the existence of rival theories that have not considered necessity of consideration in contracts and their reliance is upon commutative justice and equation in parties' bargaining power at the time of contract conclusion, is a proper room for mutuality of obligations critics. The second group of criticisms are based on the fact that mutuality of obligations doctrine has not proper function in equating parties' commitments and, in many cases, in unilateral contracts, parties can meet mutuality by inserting minor terns in the contract and turn around this rule.

On this basis, the author attempts to illuminate the concept of this doctrine and provide a right meaning of this doctrine through studying its evolution historic trend in Common Law. Upon clarifying the nature and impacts of this doctrine in Common Law, its status in mutual interest commitment of Iranian laws as well as existing legal basics and similar effects of this doctrine in Iranian laws are all studies. In fact, in Iranian laws, mutuality and correlation of parties is seen through different formats like entailment right, impossibility of commitment execution and although it is not a recognized name, its function is paid attention by jurists. Upon studying the implications of this role in Iranian laws, we study criticisms against this doctrine and its acceptance basics to complement the discussion. 


\section{Definition}

\subsection{Common Law}

"Mutuality of Obligations" or "Mutuality" which means mutual commitments lexically is a principle in contract laws by which both parties must be bound to perform their obligations or the law will treat the agreement as if neither party is bound to perform (Note 1). On this basis, a contract to which one part is obliged while another party is not obliged lacks mutuality terms and is not obliging for neither parties. This doctrine is extracted from consideration (Note 2) in USA and UK laws.

Mutuality of obligation is used in two narrow and broad senses:

In broad sense, it asserts that lack of sanction for defendant indicates that his/her commitment does not have consideration term (Ricks, 1999). Briefly, a commitment which does not lead into legal obligation is not consideration (Joseph \& Helen, 1993; Samuel, 1903/1921). Broad sense of mutuality of obligation is on conclusion step of contract and in order to be recognized valid in Common Laws, is should be consideration in terms of actions or leave of action or in cash alongside other terms such as offer and acceptance, parties' competency, legality of contract terms (Bronaugh, 1976). Lack of mutuality in parties' commitments indicates not realization of consideration and, as a result, leads to contract cancellation.

In contrast, in the narrow sense, the necessity of mutuality of obligation is the possibility of parties' actions against each other. In other words, the necessity of parties' equality against the court is the possibility of exchangeable commitments for each other (Note 3). In fact, in this concept, consideration term indicates that this is a contract not a unilateral commitment. Also, it proves that parties are entered a binding contract (Note 4). In contrary, mutuality of obligation focuses on legality of commitment exchanges and asserts that both parties should bind the contract or none of them should bind. In other words, this doctrine asserts that each commitment of the contract should be binding. Therefore, there are many hypotheses in which consideration term exists but parties' binding to contract is impossible due to lack of mutuality of obligations. For instance, consider a contract in which parties have accepted exchanges with proper and rational values while the contract includes terms by which one party losses all possible guidelines to bind another party like a contract in which the option of cancelling the contract due to not executing the commitments is eliminated (Note 5).

Studying historic trend and judicial procedure indicates that today using mutuality of obligation doctrines in its broad sense is not so considered by courts and in most cases, general propensity of judicial procedure is on using narrow sense of this doctrine.

\subsection{Iranian Laws}

In Iranian law, obligation is defined as "a legal relationship between two persons by which committer can oblige obligee to pay a sum or to transfer something or to perform his/her commitment (act or omission of something)" (Jafari \& Mohammad, 1993). In defining the pillars of commitment, one can read that in addition to subject of commitment, certainty of obligation albeit in brief and etc., making a demand, debt and one or more rights of enforcing are necessary (Note 6). On this basis, in Iranian laws and jurisprudence, if there is no engaged and enforceable person for obligation, no commitment is shaped in general meaning. In both common law and Iranian laws, any commitment for committed and committer creates legal rights and obligations, in fact, obligee has duties obligator. For instance, he/she is tasked to be delivered the asset mentioned in a contract in predetermined date. If not, it is possible to oblige him/her or to compensate losses against committer. There are a lot samples of obligations by committed in Iranian laws and in many obligations; it is not possible to execute commitment without his/her cooperation. Therefore committed person has the task to provide possibility of executing commitment in a manner so that the committer person could do his/her assignments and to receive what he/she merits. For instance, execution of treatment commitment by physician is not possible without the cooperation of patient (Shoarian, 2012). As result, in the case of lack of cooperation by committed by which commitment is unenforceable, it is the committer person who has the right to cancel the contract due to promise breaching (Note 6). Now, the amount of correlation and mutuality of obligations in Iranian laws should become clear. In Iranian laws and jurisprudence, mutuality of obligation is manifested in transfer of ownership (article 338 of Civil Laws) and mutuality in submission of subject of contract (article 362 of Civil Laws). (Jafari \& Mohammad, 2002) Although ownership transfer is realized through offer and acceptance in Iranian laws (article 338 of Civil Laws), it is an introduction to emerge the impacts of sale on submission (Note 7) subjected to article 362 of Civil Laws. Therefore, one can observe that correlation and parties' mutuality in bilateral contracts are undistinguishable components of these contracts so that even lawmaker and legal doctrine have not determined consideration in gratuitous contract like gifts as mutual obligation and have not imposed the verdicts of bilateral contracts for it (Mohammadi \& Seyed, 2012). It has another other symbols in Iranian laws. For instance, subject 
of contract in bilateral contract should have value and rational and legitimate interests (Ansary, 1411). For instance, selling a house for a gram of chocolate does not convert it into a bilateral contract. In the case of signing such contract, one of considerations lacks rational interest and one cannot consider any interest for committed person and enforcing of such obligation is meaningless in this regard.

\section{The Basics of Accepting Mutuality of Obligation Doctrine}

In defending mutuality of obligation doctrine, one can refer to below reasons:

\subsection{Attention to the Nature of Bilateral Contracts}

In bilateral contracts, each party achieves goods or estate or a mutual obligation against submitting property or obligation for an action or omission of an action. Nature of bilateral contracts in both Iranian and Common Laws is defined by the same mutuality of considerations. In fact, the existence of mutuality in UK laws is realized on the basis of consideration and Iranian laws, if an obligation lacks proper consideration is cancelled since it is non-rational and such contract is not categorized as gratuitous contract (Katuzian, 1979). In both countries, if there is no mutuality on contractual obligations, it is not seen as bilateral contract. For instance, in Iranian laws, donor can ask for consideration against gift. In Iranian laws, this is a gratuitous contract since there is no mutuality and correlation between parties (Mohammadi \& Safavi, 2012).

\subsection{The Necessity of Parties' Equality for Courts}

In the case that a bilateral contract is concluded, the necessity of parties' equality for court affirms that each party has the possibility of binding other party through referring to the court and there is no reason to make discriminate in favor of one party, there is no mutual commitment and as seen, the necessity to performing commitments reciprocally, lien in performing of contract and ... shows mutuality doctrine in narrow sense (Note 8 ) and in such case, parties equality in using legal requirement is provided. It is not unique to UK courts and is applied in Iranian laws too.

\section{The Examples of Mutuality of Obligations in Iranian Laws}

In Iranian laws, the samples of necessity of mutuality of obligations are seen including the impossibility of submission termination option, lien, correlation between considerations and ... that explained below:

\subsection{Correlation of Considerations}

The ultimate cause of parties in bilateral contract to accept a commitment is the obligation by another party. Parties rely upon correlation with each other so that breaching the commitment by one party would exempt the other one from conducting his/her commitments (Emami, 2004). On this basis, whenever it is conventionally and rationally predictable that other party is not able to perform its commitments, other party should be allowed to cancel or at least to suspend commitment execution and his/her binding to execute commitment (without commitment execution by another party) are in contrary to parties' correlation. In Iranian laws, there are some legal samples in this regard. For instance, article 238 of Commerce Law reads:

"If some accepts a bill of exchange but waives paying its sum, owner of it can object and ask him to give a guarantee or ensure another way of payment for another bill of exchange that same person accept but it had not been due." However, the guarantee of executing such waiving is not predicted in law and one can ask the court for binding the accepting part by general rules. As a result, it seems that correlation of considerations theory does not limit to lack of performing the commitment on time and one can expand its scope to pre-execution by a broad description (Rabei \& Kazemi, 2012). Today, it has manifested in comparative laws and international conventions in the format of enforcement for foreseeable breaches. In fact, in the case of clear notification by committed part to not executing the commitment or if it is hypothetically become clear that he lacks the ability to conduct its commitment in-time, executive guarantees like guarantee demand right, cancelation right (option) or contract suspension have been predicted (Note 9). It becomes clear that mutuality in performing of obligations plays a vital role in assuring contract parties so that any disorder in such mutuality would have heavy executive guarantees for breach of contract.

\subsection{Lien in Executing the Obligations}

Another implication of using this rule is lien in executing obligations. As determined in studying the historic trend of the subject in common laws, binding to execute obligation exists if such enforcing is possible also for another party. The same issue is referred in Iranian laws on lien and one author has stated:

"A group of authors believe that lien is due exchange and say that since ownership is created for parties simultaneously, submission of contract subject should be also happened simultaneously. Therefore, there is no binding to submit before that" (Najafi, 1400) and other say that by commutative justice affirms that two 
obligations should be committed in one time and there should be no prejudice. It is so important for both sides that if they have to submit their obligation without receiving what they expected in the contract, they will feel injustice since there is the risk that another party cannot perform its commitment due to insolvency or loss of subject or fault of contract party or third party. The important result from such correlation is that both sides can postpone executing their obligations to submission of contract subject (the commitment by another party). This option which suspends obligation execution without contract cancellation is so-called lien (Katuzian, 2002).

\subsection{Impossibility of Waiver of Option for Impossibility of Submission of Subject}

Another important point in contracts is not possible to incorporate waiver of option for impossibility of submission of subject: "gathering both the commitments for example goods and price in favor of one parties of the contract is Contrary to public order, so such condition is cancelled and cannot be origination of impact (Katuzian, 1997). In fact, impossibility of submission termination option means execution of commitment by only one party and such mutual consent in bilateral contracts is corrupted and cannot say that is contract by two wills (Katuzian, 2004). Hence, in civil law and jurisprudence, one can use such option when the way to enforce customer to pay the price to seller is blocked. Therefore, one cannot block the way of posing the right of seller through impossibility of submission termination option (Jafari \& Mohammad, 1994) and pose such clear unjustice against him/her (Banayi, 2012). In the case of familiarity with the function of mutuality of obligation doctrine, there remains no need to assign such ambiguous concepts like public order, justice, fairness and so on and, in fact, such commitment is no binding for parties due to breaching the necessity of mutuality of obligations. Therefore, in Iranian jurisprudence and laws, correlation of commitments and the necessity of executing mutual obligations have been always respected and relevant jurists and jurisprudents are familiar with them. Anyhow, it is necessary to consider the difference of mutuality of obligations doctrine and the rightness of urgent contracts in Iranian laws and comparative ones since the impossibility of executing non-mutual obligations is not in contrary to the rightness of such transaction. In Iranian jurisprudence and laws as well as foreign laws, urgent transaction are considered as right and it is believed that in urgent contracts although balance of parties is scattered to some extent, the urgent person has healthy will and as the result such contract is right (Seyed, 2013). To this end, one should say that the necessity of mutuality of obligation differs from urgent contracts. In fact, studying the existence or nonexistence of mutual obligations is not the radical problem of parties wills; rather, the main problem is on the right of biding parties mutually. In fact, if a contract is concluded urgently, it has no rational and proper consideration but as mentioned before, mutuality of obligation differs from consideration in contracts. In other words, in all existing assumption, urgent person has the right of execution and demanding the execution of the contract and these two issues should not be confused in discussion.

\section{Conclusion}

Mutuality of obligations doctrine has a long history in Common Law and its emergence is a little after shaping consideration theory to which it relates completely. As studies indicate, some jurists believe that one condition of consideration is the mutuality of obligations while others believe that mutuality of obligations has different meaning with consideration and it means the right of mutual bind. However, present study indicates that the first through has negative and broad sense on mutuality of obligations doctrine while the second theory has positive narrow sense for it.

In Iranian laws, the necessity of mutuality in ownership and its impacts on creating the lien and not executing mutual obligation as well as the necessity of parties correlation and respecting the nature of replaced contracts is well recognized by jurisprudents and jurists and such implications as parties correlation rule and the lien indicates that although mutuality of obligations has no record in our jurisprudence and laws, above implications indicate the impacts of such doctrine in Iranian jurisprudence and laws. The author believes that considering the functions of such doctrine in unilateral contracts and its narrow sense in our jurisprudence and laws, one can consider parties' correlation in commitments as a civil law term.

\section{References}

Ansary, S. M. (1411 Lunar). Makaseb, Qom. Dar Al-Zakhayer Publications.

Banaei, O. M. (2012). Compulsory and voluntarily liquidation of canceled contract. Civil Law bimonthly.

Banayi, O. M. (2012). Enforced and voluntarily liquidation. Civil Law Bi-Quarterly, 2, 52-53.

Bronaugh, R. (1976). Agreement, Mistake, and Objectivity in the Bargain Theory of Conflict. William \& Mary Law Review, pp. 31.

Emami, S. H. (2004). Civil Laws (28th Ed.) (Vol. 1, pp. 226). Islamic Publications, Tehran. 
Jafari, L., \& Mohammad, J. (1994). Obligation laws (2nd Eds.), pp. 14. Tehran, Univeristy of Tehran.

Jafari, L., \& Mohammad, J. (1994). Civil and commerce laws encyclopedia (Vol. 1), pp. 493. Tehran, Sepehr Publications.

Jafari, L., \& Mohammad, J. (2002). Equation theory (2nd Eds.), pp. 55. Tehran, Ganj Danesh.

Joseph, M. P., \& Helen, H. B. (1993). Corbin on co reacts Lexis Nexis (Revised Eds.).

Katuzian, N. (1997). Contracts' general rules (2nd Ed.), pp. 398. Enteshar Company.

Katuzian, N. (2002). Civil laws, legal actions (contract) (8th Ed.), pp. 240. Tehran, Mizan.

Katuzian, N. (2004). Preliminary civil laws course (Vol. 2), pp. 304. Mizan Publications.

Katuzian, N. (1999). Legal actions preliminary course (7th Ed.), pp. 28 - 29. Enteshar Company.

Kazempour, S. J. (2013). Supporting urgent person in urgency contracts; basics and guidelines. Legal Journal, $80,12-14$.

Mohammadi, M., \& Seyed, S. S. (2012). Studying consideration jurisprudential and legal nature in non-exchanged contracts by emphasis on gift contract, the 1st National Legal Philosophy by Emphasis on Islamic Laws Philosophy, pp. 1. Ramhormoz, Azad Islamic University. Retrieved from http://www.civilica.com/Paper-ISLAMICLAW01-ISLAMICLAW01_039.html

Najafi, M. H. (1400 Lunar Year). Jawaher Al-Kalam Fi Sharh Sharye Al-Isla (Vol. 23) (7th Ed.), pp. 144. Darolkotob Islamic.

Ostadi, M., \& Parsapour, M. T. (2014). Executive guarantee of delay in paying contract prices. Comparative Law Researches (Vol. 2), pp. 19.

Ostadi, M., \& Ricks, V. (1999). In Defense of Mutuality of Obligation: Why "Both Should Be Bound, or Neither”. Nebraska Law Review, 78(3), 494.

Rabei, M., \& Kazemi, M. (2012). Possible breach of contracts in Iranian laws by looking at International Sales Convention (1980) and other foreign legal systems. Civil Law bimonthly, 1, 107.

Safaei, S. H. (2004). Civil law preliminary course (Vol. 2). Mizan Publications.

Samuel, L. W. (1903/1921). A selection of cases on the law of contracts. University of Michigan Library.

Shahidi, M. (2008). Contract Implied terms (2nd Ed.). Majd Publications.

Shoarian, E. (2012). Committed person's cooperation in contract execution. Private Laws Journal, 18, pp. 109.

\section{Note}

Note 1. Unless both parties to a contract are bound to perform, neither party is bound, see: West's Encyclopedia of American Law, edition 2. Copyright 2008 the Gale Group.

Note 2. According to "consideration" doctrine, a commitment is obliging only against a value or commitment. Differences between mutuality doctrine and consideration doctrine are explained in the second article in detail.

Note 3. Ricks, op.cit, p 516.

Note 4. Bronaugh, op.cit, p 32.

Note 5. In this case, a detail study is provided in the paper.

Note 6. Ibid.

Note 7. Ibid: 58.

Note 8. Ricks, op.cit, pp. 516-522.

Note 9. Rabei and Kazemi, ibid, p 108.

\section{Copyrights}

Copyright for this article is retained by the author(s), with first publication rights granted to the journal.

This is an open-access article distributed under the terms and conditions of the Creative Commons Attribution license (http://creativecommons.org/licenses/by/4.0/). 